UDC 821.111-342(71)

DOI https://doi.org/10.32782/tps2663-4880/2019.11-2.24

\title{
TIMOTHY FINDLEY AND ALICE MUNRO AS DIAMONDS OF CANADIAN LITERATURE
}

\section{ТІМОТІ ФІНДЛІ ТА ЕЛІС МАНРО ЯК ДІАМАНТИ КАНАДСЬКОЇ ЛІТЕРАТУРИ}

\author{
Chernova Yu.V. \\ orcid.org/0000-0001-7977-1358 \\ Lecturer at the Department of Theory and Practice of English Translation
} Petro Mohyla Black Sea National University

The research is aimed at students and others who study contemporary foreign literature and Canadian literature in particular. It may interest everyone who is engaged in history and culture of Canada. The research emphasizes the most outstanding Canadian prose writers such as Alice Munro and Timothy Findley, and gives short summaries of some of their works after brief biographical data about each author. The article underlines that Canadian literature is now being actively researched in Ukraine and it is worth of being analyzed as it can boast of many outstanding writers. The short stories of two of them, famous and prolific Canadians Findley and Munro, have been chosen as the material for this article. The article emphasizes the genre of the short story in Canadian literature and is based on such short stories as Dreams by Findley and the short story collection Dear Life by Munro. The analysis of each block begins with short data about the author and continues by underlining details of the stories as the distinctive style of the author. Psychological peculiarities of each author's writing are discussed. The short list of the researchers who have analyzed the same issue is also submitted. Timothy Findley is usually perceived as a writer of serious prose and only some of his admirers know that the Canadian has some bright examples of the short story genre. One of his works in this area is highlighted in the article. On the contrary Alice Munro is famous for her short stories but usually names of these pieces or collections of stories can't be enumerated by students either. This paper draws the attention of readers to one of Munro's collections of short stories that also features autobiographical elements. In general the article tries to give the audience an impression that Canadian literature is unique in its style and boasts eminent authors with high writing standards.

Key words: Canadian literature, short story, Timothy Findley, Alice Munro, Canadian Chekhov.

Дослідження націлено на студентів та інших, хто вивчає сучасну іноземну літературу та канадську літературу зокрема. Стаття може зацікавити всіх, хто тим чи іншим чином пов'язаний з історією та культурою Канади. Дослідження робить акцент на найвидатніших канадських прозаїках Еліс Манро та Тімоті Фіндлі та надає короткий нарис деяких творів, що їм належать, після короткої біографічної довідки про кожного з автора. Робота підкреслює, що канадська література зараз активно досліджується в Україні, і вона дійсно того варта, адже Канада може похвалитися безліччю талановитих літераторів. Короткі оповідання двох з них, відомих та плідних Манро та Фіндлі, були обрані як матеріал для даного дослідження, яке акцентує увагу на жанрі короткого канадського оповідання та базується на історії Сни Тімоті Фіндлі та збірці оповідань Еліс Манро під назвою Дороге Життя. Аналіз кожної частини розпочинається зі стислих відомостей про автора та продовжується виокремленням характерних деталей стилю письма прозаїка. Психологічні особливості оповіді також обговорюються. Короткий список учених, що займалися дослідженням цього жанру, надається. Тімоті Фіндлі зазвичай сприймається як творець серйозної прози, тому лише небагато з його шанувальників знають, що канадець має декілька яскравих прикладів у жанрі короткого оповідання. На одному з них акцентується увага у статті. Еліс Манро навпаки відома загалу своїми короткими історіями, проте зазвичай їх назви або назви збірок не можуть бути перераховані учнями. Стаття привертає увагу читачів до однієї із збірок оповідань Манро, яка містить автобіографічні моменти. В цілому робота намагається надати аудиторії враження, що канадська література унікальна у своєму стилі та може похвалитися видатними авторами з високими стандартами письма.

Ключові слова: канадська література, коротке оповідання, Тімоті Фіндлі, Еліс Манро, канадський Чехов.

The definition of the problem: The genre of short Canadian story is usually associated by students and even researchers with Alice Munro but just few know the plot itself of all her stories. As a result this paper analyses her oeuvre by not only underlining her style but by rendering the main events of this or that piece from the collection Dear Life.

The researchers that analyzed the material. Canadian short story was discussed by Gerald Lynch and Angela Arnold Robbeson in their Essays on the Canadian Short Story, W.J. Keith, Alistair MacLeod in his essay "The Canadian Short Story", Katarina Korosiova in her Master's Diploma Thesis
"The Canadian Short Story". The oeuvre of Timothy Findley was analyzed by Latham Hunter, Diana Brydon and Peter Stevens. The style of Alice Munro was examined by Brad Hooper, W.R. Martin, Joann McCaig, Isla Duncan, Patel Aloka, Amelia DeFalco.

The part of the problem usually not solved. Moreover few only know that one of the representatives of the short story genre is Timothy Findley whose unforgettable knack of making readers feel what the characters feel is unforgettable. So the paper gives an opportunity to discover one of his best short stories Dreams and the aim is to make readers perceive Findley not only as a proser but as a short story 
writer as well. Another aim is to reveal as many pieces by Munro as possible for an average reader.

The main part. Timothy Findley (1930-2002) began his artistic career studying dance and then later theater. His first success as a novelist didn't come in Canada. His first two novels were rejected by Canadian publishers and were in the end published in Britain. The situation changed with "The Wars" (1977) which won a prestigious award and was adapted for film. Findley continued to write establishing his reputation as one of the most beloved Canadian writers. The novel by him "Not Wanted on the Voyage" (1986) remains one of his most popular and is a retelling of the biblical story of Noah and his journey on the ark. "The Telling of Lies" (1989) won an award for mystery writing. The success was followed by "Headhunter" (1993), a dark and futuristic novel. In 1999 Findley published one of the most ambitious novels of his, "Pilgrim", the story of a seemingly immortal man. Also wrote scripts for film and television. As a teenager admitted being homosexual. Timothy Findley was briefly married to the actress, but their marriage lasted only three month. Then he got together with his lifetime friend, the screenwriter Bill Whitehead, and they spent the rest of their lives together. Margaret Atwood was Findley's friend. The writer admired the work of Russian writer Anton Chekhov.

In his short story Dreams Findley potently touches deep and provocative theme of psychiatrists' hard work and mental disorders they deal with every day. The plot line is all around a married couple Menlos who both work in this sphere but at different establishments. Everett's area is schizophrenia and Mimi is devoted to autistic children. The spouses strictly follow the ethics of their profession together and always share some working issues with each other. Suddenly Everett stops sleeping at night and his caring wife has no notion why as he refuses to talk about that. Step by step it gets clear that the problem is about Dr. Menlo's patient Kenneth Albright who is schizophrenic and inclined to suicide. After some productive spell of sharing his unique dreams with the treating doctor Albright stops talking at all and one day he is found in the ward with blood stains all over his body. Nobody including Everett Menlo has a reasonable explanation of what has happened and where the blood appeared from. That marks the end of Dr. Menlo's composure. He starts torturing himself with different thoughts and assumptions but still can't understand where his patient could find the blood since Kenneth himself was never found wounded or injured and other patients either. Night after night Everett in his dreams sees Albright bending over some dead body and he realizes that he might have been the man Kenneth killed in the dreams of both. He starts suffering from serious insomnia as he is scared to close his eyes. He is sure the moment he does it he will be murdered by his own patient. Meanwhile Everett's wife Mimi also faces a tough situation at work: her eight-year-old patient Brian Bassett is severely autistic and refuses not only to react somehow to the outer world but to eat as well and is nothing but dying now. Mimi who is even called by her colleagues "Bassett's crazy guardian angel" does whatever she can to ease the pain of the silent child. He is losing his weight extremely fast and Mimi is fully aware that this is the end. She realizes such children come to this world against their will and just nothing could hold them here. At the very last moment the boy says Goodbye to Mimi and dies. Shocking end of this story makes Findley's readers be scared of their own dreams but one should know that first of all the plot emphasizes extremely hard job of doctors who deal with mind disorders and in the case of the Menlos if they take it too personally it can ruin their own health and composure. The couple in the story Dreams doesn't have children and it might be the reason why they both concern about their patients' health so much. The role of their child is given to the dog of an unknown breed which strangely enough also has nerve-wrecking dreams. Everybody in the story is closely connected through those concerns they have about people they care about.

Alice Munro (born in 1931) was the first Canadian ever to win the Nobel Prize in Literature in 2013. She is called Canadian Chekhov and was immortalized on Canadian currency. The acclaimed short-story writer appeared on a silver collector's coin, joining Jane Austen and Astrid Lindgren, who appeared on UK and Swedish banknotes respectively. J. Moss stated: "Her prose is clear and unclutterd. She exhibits meticulous control over narrative voice and situation. She effortlessly evokes mood and manipulates response". But Munro is not a simple writer. Time and place in her stories are real and therefore readers are bewildered because they have already fallen out of the habit to read something non-complicated. Munro portrays the worlds of women and girls, and every time it is an absolutely new world and by being shared in recollection it causes an effect of déjà vu.

Munro was greatly supported by Margaret Laurence in the $60 \mathrm{~s}$ and is still admired by Margaret Atwood. The world of short stories by Alice Munro gives us a chance to cry with her characters and these tears can be both of happiness and sadness. Each plot of hers is a separate, unique and self-contained microcosm where a woman can do something we would never dare in the real life. In the short story To Reach Japan Munro introduces Greta, mother 
of a little girl and wife of Peter, an engineer. Step by step it becomes obvious that Greta in her family life is not blissfully happy, after all having been invited to a writers' gathering, as she also writes, Greta meets an unknown man. They leave the party together and the man, who turns out to have a name Harris, gives her a lift. There is already something invisible between them and this "something" doesn't let Greta sleep. Is she allowed to behave like that being a married lady? Does she have that right to leave everything behind and start it all over again? We are readers but are we to judge? Greta is going to spend some time with her daughter in Toronto, and before her trip she writes a note to Harris. We finally can understand the title of the story since the main character finishes her short letter with some special stylistic comparison where she underlines that "writing this letter is like putting a note in a bottle - and hoping it will reach Japan" [3; p. 14]. Greta has no distinct hope but still tries to grasp any opportunity to contact Harris and remind him about her existence. On the train to Toronto she meets some young actor and has a spontaneous sex with him and having returned to her compartment Greta realizes that her daughter has disappeared. Does Greta deserve our condemning now? Definitely she should not have left sleeping Katy in the compartment. What made her do that despair or loneliness? If she committed a sin Greta did punish herself during those minutes she spent in search of Katy. The authoress tries to make us ruin all those borders and frames a married lady is limited to. Surprisingly enough the end is happy as Katy is safe and Harris meets them at the station. Munro gives all of us a sparkling hope that we can change our lives for better even at the high price.

One more story entitled Amundsen is not that vividly positive. Vivien, a shy and inexperienced young lady, arrives at some kind of sanatorium for children with tuberculosis in order to teach them. She wants to do all she can for making sick pupils' life a bit better. Her employer, a doctor much older than her, is a very specific man that is not that easily understood. But somehow he gets attached to the new young teacher and invites her to his place where a couple becomes lovers. The story is full of touchingly sad moments as Vivien's friendship with an energetic and loud girl Mary who tells her about the closest friend's death and the situation when Mary storms into Doctor Alister's house and tries to act out some play in order to congratulate him and Vivien on Valentine's Day but minutes later she is kicked out by the host as an uninvited guest. It seems that Alister's behavior should already put Vivien off but being in love and with a lack of experience as the girl brought up by old-fashioned grandparents she is absolutely blind and accepts the doctor's marriage proposal. But something goes wrong and near the registry office Alister changes his mind. One ought to understand that this is not yet another love story with an unhappy end but some life situation you should look at from another angle - what if it happened for better? This personal tragedy remains etched in Vivien's memory forever, even being married she is still waiting for an accidental encounter with Alister but when it all happened years ago wasn't he more realistic having understood that he would only ruin this pure girl's life?

Leaving Maverley is a story which just can't leave a reader unemotional. Here we deal with that rare case when the authoress' attention is paid to a man as a protagonist. Ray Elliot as a night police officer takes home a young girl Leah after her late evening shifts at the local movies. Leah was raised in a very religious family and doesn't have permission of her father for usual things. She is absolutely innocent at many mundane things. But that would be too plain for Alice Munro and her character Leah for the society turns into a rotten apple as she disappears before the heavy snowstorm and some time later sends a letter with the explanation of what happened - she is married now to the minister's son. For Ray who never had his own children because of his wife's heart condition it was a kind of shock as he was already attached to Leah in a fatherly way. But even that was not enough for the complex life story of Leah - further she ruins the marriage of a new minister. But was she the only one to be blamed? Wasn't she seduced by her future husband being a timid and inexperienced? Didn't a new local clergyman just abuse her in order to "celebrate the life of the body along with the life of the spirit" [3; p. 85]? Why couldn't Leah say no to them? A girl should perceive Munro's plots as some kind of warning - a lady ought not to be scared to say no if she feels that she is just abused. Roy suffers much as his beloved wife Isabel gets in coma and never wakes up again. Right before Isabel's death fate makes Roy meet Leah again since she works at the same rehabilitation center. She also lost everything: her husband, her in-law's support, her lover and even her two children. The authoress lets us imagine that Leah and Roy could somehow ease each other's pain as a family of a lamenting father and an outcast daughter and it is incredible if there is such a person who is ready to soothe your sorrow. Shouldn't everyone be that person to help?

One more short story which is a part of the collection by Alice Munro Dear Life is entitled Gravel. It is narrated by the girl whose name we never know, and who shares with us vague memories from her 
childhood. The girl's mother has an affair with a young actor Neal and leaves her husband having moved with two daughters to some caravan. If the main character who is a younger girl doesn't completely understand these events her elder sister Caro bears the grudge against their mother. After all Caro feels that their father was abandoned behind and will condemn their mother's behavior. Over and over again the authoress underlines deplorable consequences of a woman's decision to change her life in an opposite direction. At first Caro secretly took their dog Blitzee to their father's house but when it doesn't change anything she decides to risk her own life. What did she want to prove? How could it have reversed their mother's intention to spend her life with another man? All these questions never leave the main character who doesn't even remember clearly what exactly happened. Probably planning somehow to attract their mother's attention Caro asks her sister to run home and cry for help, and while the child is doing what she has been asked to Caro jumps into the gravel pit full of water that was located near their place of living. Did she hope to be rescued? Definitely she did. But something went wrong. It turned out that Neal, their mother's lover, couldn't swim. The woman herself was too heavy and clumsy waiting for the third baby. Caro drowned having ruined the lives of people around her. The girls' mother and Neal broke up. Her younger sister will be tortured by those memories and questions without answers during all her life. Who is guilty in this story? A reader may condemn the sisters' mother whose light-hearted decision destroyed a normal family. But wasn't Caro's behavior also egoistic and childish? One shouldn't be biased in life situations of that kind, after all everyone at least once in their life wishes to grasp an opportunity to be happy.

In the story Haven the main character's parents leave for Ghana for some volunteering purpose and their daughter stays with her aunt Dawn and her aunt's husband Jasper. The latter is an arbitrary man who abhors social life and whose position in many life aspects is absolutely negative. Aunt Dawn is extremely shy in front of him and is forbidden from many daily joys. Why should a lady tolerate such a treatment? Here a woman is afraid to change her life contrary to the lady in the story Gravel but still nobody is happy. Symbolic meaning is given by Munro to the final episode which takes place in church at the funeral of uncle Jasper's sister. Having been separated by the choir moving in the aisle from his wife and niece Jasper is not able to join them. And aunt Dawn after all that misunderstanding simply doesn't care. Husbands from upper class who marry beneath often appear in short stories by Munro. The writer herself married a son of a senior accountant but nobody can say that James Munro didn't support his wife as a writer, he even presented Alice with the very first typewriter on her 21 nd birthday.

In the story entitled Pride surprisingly enough the protagonist, unnamed young lady, must sell her house because her friend with whom she was never even much close wants to move to her. The main character just doesn't see any other solution and it is the best possible idea she is able to come up with. Why simply not to say no to someone who wants somehow to live with her even being steered by good intentions? Skunks which unexpectedly appear at the very end of the story and drink water from the main character's late mother's birdbath make both ladies stunned and amazed and symbolize something new, but probably dire, coming into their lives.

If the main character in the above-mentioned story has a harelip as an impediment the protagonist Corrie, whose name gives the title to the next short story by Alice Munro, suffers from long-standing lameness as a result of polio she once got sick with. Somehow through her father Corrie gets acquainted with Howard Ritchie, an architect. They eventually start an affair even though the man is married. But later the girl Lillian who used to work at Corrie's house starts blackmailing them and the unlucky couple must pay her a substantial sum of money twice a year so that treacherous Lillian never tells the truth to Howard's wife. It has lasted for many years and the one who pays is Corrie because she is wealthier and can't let her lover steal money from his family. Interestingly enough Corrie never gives money to her former maid right from hand to hand but it is Howard who takes money and then probably puts it into the mailbox of Lillian. The emphasis here is on the word "probably". In the end Corrie begins to suspect that she has been abused and deceived for already a very long period of time. It is Howard who may have taken all those sums of money to fund his wife and children. Is it an upheaval for the woman? Naturally it is. Does the authoress give a chance to readers that it all might be just a wrong assumption? Yes, she does. In the yet another microcosm of a woman's life story still there is a hope that it could have been much worse.

The story Train is much longer. Jackson, a soldier coming back home from the war, suddenly jumps off his train and starts walking in the opposite direction. There ought to be someone he really doesn't want or is not just ready to see yet. By accident he meets a lonely woman Belle and stays at hers much longer than he intended to. But there is no chemistry between them and everywhere they are recognized as a brother and a sister. Life turns a new page in such 
a way that Jackson is the only one who takes care of Belle when she is dying of cancer. Some time later after the operation the man suddenly moves back one more time and having found a job as a caretaker he never sees Belle again. Is it responsibility he is afraid of? Is that the reason why he keeps abandoning all women in his life behind? Extreme shyness which was triggered by his mother's death when he was still very small might be also a reason. Potent emotions that are evoked by the plot and style of Munro make her audience imagine themselves in each story of that kind where they would probably never fall into the traps the writer's characters are already in.

More than often Alice Munro presents a blurred line between protagonists' reality and dreams as in In Sight of the Lake where an elderly woman with some memory problems is looking for the doctor's office where she has an appointment. She still has a husband and still drives a car but when the woman finds some medical establishment and enters it she sees nobody inside and just bangs on the locked doors. Seconds later it turns out that it was nothing but a dream and now the main character is absolutely helpless in hospital or probably old people's home. The locked doors in the dream may symbolize some place she will never be able to enter again and that is really sad, so one should use each moment of life to enjoy it and make better for those around.

The short story entitled Dolly is finally much more positive at its end than the rest of narrations by Munro in the collection Dear Life. An elderly couple leads rather calm life but suddenly a woman selling cosmetics and with the name Gwendolyn appears at their house and turns out to be Franklin's old friend. Love conquers all and at all ages, so even being a pensioner the main character becomes very jealous and sees something between Franklin and Dolly that doesn't really exist. She leaves their place and spends some days at the motel feeling broken and distraught. Suddenly the woman remembers her young days when she spent time with an older teacher who definitely will have had his wife and children. We all commit sins but they don't always cast long shadows. When the woman returns home she is absolutely happy with Franklin even though he was trying to kid her about some affair between him and Dolly.

The last four stories of the collection Dear Life according to the authoress' note are partly autobio- graphical. The moments described in the stories The Eye, Night, Voices and Dear Life really coincide with the events in Munro's life if one checks her biography. Her father really had a fox business that would falter later and in the story Night Munro gives a hint that she knew her father was having an affair. The authoress' mother was a teacher and really socially ambitious, drove a car that was still unusual for a married woman and was trying to bring her eldest daughter up in a kind of strictly cold way. It is true that Alice had younger brother and sister and again in the story Night the main character suffers from insomnia at night and thinks that demons possess her as she can't stop thinking of strangling her sister while her sleep. But the frank conversation with their father once at dawn helps the girl get rid of her worries and insomnia.

In the story The Eye a little girl gets close with the hired lady Sadie who probably is still a teenager. The former doesn't get on well with her mother and Sadie is the only one who somehow brightens the girl's days. But when Sadie was coming back from the dance hall she was killed in the car accident. Since the main character has never visited funerals before it is a shock for her when by her mother she is made to look at the dead body. The girl suggests that her mother is doing that deliberately to revenge for that warm relationship that was present between her daughter and Sadie.

In stories Voices and Dear Life the authoress tells her readers about her primary school where she was bullied and threatened, about three-kilometer walks every day to classes and back. Moreover one can learn that Munro's mother was ill with Parkinson's and her speech and mind were getting worse and worse. Sadly enough the writer couldn't visit her mother's funeral as she had two little children and nobody to care of them. Alice Munro finishes her final collection with the words that etch in the memory for long and in which almost everyone can recognize themselves: "We say of some things that they can't be forgiven, or that we will never forgive ourselves. But we do - we do it all the time" [3; p. 319].

The conclusion. Highlighted above authors do not constitute all the list of contemporary Canadian short story writers. It is worth of being continued and further discussed since this country's literature tradition regularly contributes new unique and compelling pieces to the world literature heritage.

\section{REFERENCES:}

1. Balachandran K. Canadian Literature: an Overview/edited by Prof. K. Balachandran, Prof. of English, Annamalai University. - Sarup and Sons, New Delhi ( $1^{\text {st }}$ edition 2007).

2. Moss J. (1981) A reader's guide to the Canadian novel. Toronto: McClelland and Stewart.

3. Munro Alice. Dear Life. - Vintage 2013/

4. New W.H. (2003) A History of Canadian Literature. McGuill-Queen's University Press.

5. The Norton Anthology of Short Fiction/R.V. Cassill. $-5^{\text {th }}$ edition. 